Research Journal of Applied Sciences 7 (4): 208-211, 2012

ISSN: $1815-932 \mathrm{X}$

(C) Medwell Journals, 2012

\title{
Bacteriological Analyses of Weaning Foods Consumed in Umuariaga Community, Ikwuano L.G.A. Abia State
}

\author{
C.N. Obi and N.C. Nwozor \\ Department of Microbiology, College of Natural and Applied Sciences, \\ Michael Okpara University of Agriculture, Umudike, P.M.B. 7267, \\ Umuahia, Abia State, Nigeria
}

\begin{abstract}
Weaning foods fed to infants aged between 2-10 months old from Umuariaga community were subjected to bacteriological analyses. All the food samples analyzed (dawa, pap, custard, Golden Morn and Quaker oats) were contaminated bacteria isolated from the collected food samples were Staphyloccocus aureus, Escherichia coli, Lactobacillus plantarum and Streptococcus thermophillus. The total heterotrophic bacterial counts of the food samples were highest for dawa followed by pap collected from uneducated mothers with counts of $4.43 \times 10^{5}$ and $4.07 \times 10^{5} \mathrm{cfu} \mathrm{mL}^{-1}$, respectively while the least total heterotrophic bacterial counts were recorded for Quaker oats followed by Golden Morn from educated mothers with counts of $2.13 \times 10^{5}$ and $2.24 \times 10^{5} \mathrm{cfu} \mathrm{mL}^{-1}$, respectively. The total coliform count $\left(2.63 .0 \times 10^{5} \mathrm{cfu} \mathrm{mL}^{-1}\right)$ was highest for pap from uneducated mothers while the least coliform count $\left(1.76 \times 10^{5} \mathrm{cfu} \mathrm{mL}^{-1}\right)$ was from Golden Morn collected from educated mothers. The presence of food pathogens poses a big threat to the health of the infants therefore, proper hygienic handling of weaning foods from production to consumption is recommended.
\end{abstract}

$\underline{\text { Key words: Bacteria, hygiene, infants, pathogens, weaning foods, Nigeria }}$

\section{INTRODUCTION}

Weaning period is a time when a new feeding method apart from the mother's breast milk is introduced to a baby. This period which could start from 4-6 months of age a time when breast feeding is not sufficient to supply enough nutrients for optimum growth varies from one socio-economic status to another. Furthermore, variations occur in the type form and use of baby foods.

Infant formula is usually the first kind of weaning food introduced to infants due to its semi-solid form when prepared. It supplies the right balance of fats, carbohydrates and proteins. Hence, it is also a good supplement for mothers due to its similarity to breast milk. However, most of the additional weaning foods are of low nutritional value (Bekebian, 1989).

Infants ought to be adequately nourished so as to maintain a good physical and mental state. This is a big challenge to many nursing mothers in Nigeria, especially those of middle socio-economic class as they find it difficult to provide good quality and nutritionally balanced weaning foods for their babies as these are usually costly. Due to this cost problem, these mothers end up resorting to traditional weaning foods like pap (fermented maize) popularly called ogi and fermented sorghum popularly called dawa. These foods do not contain the essential nutrient for healthy development of a child (Ashaye et al., 2000).

Weaning foods prepared under unhygienic conditions are shown to be heavily contaminated with pathogenic microorganisms. This is a major risk factor in the transmission of diseases, especially diarrhoea. Contaminated hands and cooking utensils also contribute greatly to the contamination of weaning foods, especially among mothers who do not observe proper hygienic measures like washing of hands after changing nappies and those that leave the preparation of weaning foods and feeding of the same to the babies solely in the hands of their maids (Bryan, 1988).

Water used for the preparation of the weaning foods itself is also a major source of contamination, especially if not boiled properly. This is because many of these mothers obtain their water from wells, streams, rain or boreholes and these waters are not given any form of treatment. Insufficient cooking is also another factor highly prevalent in the preparation of pap, dawa and custard which does not involve long period of heating the gruel. This poor heating treatment enables the survival of

Corresponding Author: C.N. Obi, Department of Microbiology, College of Natural and Applied Sciences, Michael Okpara University of Agriculture, Umudike, P.M.B. 7267, Umuahia, Abia State, Nigeria 
many pathogens in the weaning food (Bryan, 1988). To this end, this research work was carriedout in 2010 to determine the bacteriological quality of weaning foods consumed in Umuariaga community.

\section{MATERIALS AND METHODS}

Sample collection: Samples of prepared weaning foods were collected from the nursing mothers from different families in Umuariaga community using universal sterile bottles. The food samples were collected just before they were consumed. They include pap (ogi), dawa, custard, Golden Morn and Quaker oats. Households with infants aged between 2-8 months old were used for this study. The food samples were kept in coolers containing ice cubes and transferred to the laboratory for analyses. During the period of this research, mothers were interviewed on their level of formal education, types of weaning food used, preparation and storage methods; time of cooking and consumption.

Bacteriological analyses: About $1 \mathrm{~g}$ of each collected food sample was homogenized in $9 \mathrm{~mL}$ of normal saline and serially diluted (Obi et al., 2005). About $0.1 \mathrm{~mL}$ of suitable dilution was inoculated in duplicates onto Nutrient and McConkey agars, spread with sterile bent glass rod and incubated at $37^{\circ} \mathrm{C}$ for $24 \mathrm{~h}$. Total heterotrophic plate counts and total coliform counts were determined from the nutrient and McConkey agars, respectively. Each bacterial isolate was sub-cultured on fresh media using streaking technique to obtain pure cultures. The pure cultures were gram stained and also, subjected to the necessary biochemical tests for proper identifications (Ogbulie et al., 1998; Chessbrough, 2000).

\section{RESULTS}

Weaning food samples collected from various nursing mothers were bacteriologically analyzed. On Table 1 shows the Total Heterotrophic Bacterial Counts (THBC) with dawa samples having the highest mean THBC of $4.43 \times 10^{5} \mathrm{cfu} \mathrm{mL}^{-1}$ and the least THBC from Quaker oats samples with $2.13 \times 10^{5} \mathrm{cfu} \mathrm{mL}^{-1}$ value. Table 2 shows the THBC of the food samples from the various categories of nursing mothers with uneducated mothers having the highest mean THBC of $4.23 \times 10^{5} \mathrm{cfu} \mathrm{mL}^{-1}$ while the educated mothers gave the lowest mean THBC of $2.80 \times 10^{5} \mathrm{cfu} \mathrm{mL}^{-1}$. On Table 3 shows the total coliform counts of the food samples collected from various nursing mothers with the uneducated mothers giving highest mean coliform count of $2.63 \times 10^{5} \mathrm{cfu} \mathrm{mL}^{-1}$ (highest individual count is from pap:
Table 1: Total heterotrophic bacterial counts of weaning food samples (105 $\left.\mathrm{cfu} \mathrm{mL}^{-1}\right)$

\begin{tabular}{|c|c|c|c|c|c|}
\hline $\mathrm{S} / \mathrm{NO}$ & Custard & Pap & Dawa & $\begin{array}{l}\text { Quaker } \\
\text { oats }\end{array}$ & $\begin{array}{c}\text { Golden } \\
\text { Morn } \\
\end{array}$ \\
\hline 1 & $3.6^{\mathrm{sm}}$ & $3.80^{\mathrm{un}}$ & $5.3^{\mathrm{un}}$ & $3.0^{\mathrm{sm}}$ & $2.30^{\text {ed }}$ \\
\hline 2 & $3.9^{h w}$ & $4.70^{\mathrm{cm}}$ & $4.8^{\mathrm{sm}}$ & $2.3^{\text {ed }}$ & $1.60^{\mathrm{ed}}$ \\
\hline 3 & $2.8^{\mathrm{sm}}$ & $3.50^{\mathrm{cm}}$ & $4.4^{\mathrm{un}}$ & $2.8^{\mathrm{sm}}$ & $2.40^{\mathrm{ed}}$ \\
\hline 4 & $4.2^{\mathrm{sm}}$ & $4.60^{\mathrm{hw}}$ & $3.8^{\text {un }}$ & $2.1^{\mathrm{ed}}$ & $1.90^{\mathrm{cm}}$ \\
\hline 5 & $4.8^{\text {un }}$ & $3.70^{\text {ed }}$ & $5.2^{\mathrm{hw}}$ & $1.6^{\mathrm{ed}}$ & $2.50^{\mathrm{hw}}$ \\
\hline 6 & $3.2^{\mathrm{un}}$ & $3.80^{\mathrm{cm}}$ & $4.1^{\mathrm{sm}}$ & $1.3^{\mathrm{ed}}$ & $2.80^{\mathrm{hw}}$ \\
\hline 7 & $3.0^{e d}$ & $3.60^{\mathrm{un}}$ & $4.3^{\mathrm{un}}$ & $1.8^{\mathrm{sm}}$ & $1.70^{\mathrm{ed}}$ \\
\hline 8 & $3.7^{\mathrm{sm}}$ & $4.80^{\mathrm{mn}}$ & $3.6^{\mathrm{ed}}$ & SU & $2.90^{\mathrm{cm}}$ \\
\hline 9 & $3.3^{\mathrm{hw}}$ & $3.90^{\mathrm{cm}}$ & SU & SU & $2.80^{\text {ed }}$ \\
\hline 10 & $\mathrm{SU}$ & $4.30^{\mathrm{hw}}$ & $\mathrm{SU}$ & $\mathrm{SU}$ & $1.50^{\mathrm{cm}}$ \\
\hline $\begin{array}{l}\text { Mean bacterial } \\
\text { counts }\end{array}$ & 3.61 & 4.07 & 4.43 & 2.13 & 2.24 \\
\hline
\end{tabular}

$\mathrm{sm}=$ student mothers; hw = house wives; $\mathrm{un}=$ uneducated; ed = educated; $\mathrm{SU}=$ Sample Unavailable

Table 2: Mean heterotrophic bacterial counts of food samples from different mothers (105 $\mathrm{cfu} \mathrm{mL}^{-1}$ )

\begin{tabular}{llccc}
\hline Sample & Uneducated & House wives & Student mothers & Educated \\
\hline Pap & 4.40 & 3.90 & 3.90 & 3.60 \\
Custard & 3.60 & 3.10 & 3.50 & 3.00 \\
Dawa & 4.70 & 4.20 & 4.40 & 3.40 \\
Quaker oats & SU & 2.40 & 2.30 & 1.80 \\
Golden Mom & SU & 2.30 & 2.40 & 2.20 \\
Mean bacterial & 4.23 & 3.18 & 3.30 & 2.80 \\
counts & & & & \\
\hline
\end{tabular}

$\mathrm{SU}=$ Sample Unavailable

Table 3: Mean coliform counts of food samples from different mothers $\left(105 \mathrm{cfu} \mathrm{mL}^{-1}\right)$

Food samples Educated Uneducated Student mothers House wives

\begin{tabular}{lllll}
\hline Pap & 2.40 & 3.00 & 2.40 & 2.20
\end{tabular}

$\begin{array}{lllll}\text { Custard } & 1.80 & 2.10 & 2.00 & 1.60\end{array}$

$\begin{array}{lllll}\text { Dawa } & 1.70 & 2.80 & 2.60 & 2.50\end{array}$

$\begin{array}{lllll}\text { Quaker oaks } & 1.50 & \mathrm{SU} & 1.60 & 1.60\end{array}$

$\begin{array}{lllll}\text { Golden Mom } & 1.40 & \mathrm{SU} & 1.80 & 1.30\end{array}$

$\begin{array}{lllll}\text { Mean coliform } & 1.76 & 2.63 & 2.08 & 1.84\end{array}$

counts

$\mathrm{SU}=$ Sample Unavailable

$3.00 \times 10^{5} \mathrm{cfu} \mathrm{mL}^{-1}$ ) and the lowest mean coliform count $\left(1.76 \times 10^{5} \mathrm{cfu} \mathrm{mL}^{-1}\right)$ from the educated mothers with Golden morn giving the lowest individual yield of $1.40 \times 10^{5} \mathrm{cfu} \mathrm{mL}^{-1}$.

\section{DISCUSSION}

Microbiological analyses of the weaning food samples analysed above showed the presence of Escherichia coli, Staphylococcus aureus, Lactobaccillus plantarum and Streptococcus thermophillus in all the weaning food samples. The presence of $E$. coli and $S$. aureus which are known food pathogens suggests high risk of infection and intoxication.

This finding reflect the trend reported by other investigators (Obi et al., 2005; Ifediora et al., 2006) who result showed that weaning food contaminated with the pathogens are important in transmitting diarrhoeal pathogen especially, E. coli. 
Result from Table 1 showed that dawa and pap had the highest THBC $\left(4.43 \times 10^{5}\right.$ and $4.07 \times 10^{5} \mathrm{cfu} \mathrm{mL}^{-1}$, respectively). The fermentation conditions attributes of these food samples were supposed to eliminate the presence of the pathogens that were possibly present as contaminant before the raw materials (sorghum and maize, respectively) were fermented for the production of the weaning foods (dawa and pap). L. plantarum produces lactic acid, bacteriocins, hydrogen peroxide, carbon (IV) oxide (Leroy et al., 2006) and these compounds are known to inhibit pathogens present in the fermentative vats. Hence, the presence of these pathogens and their numerical strength strongly suggest contamination by post fermentation processes such as handling during processing, storage and preparation with contaminated water (mainly waters from rainfall, wells and untreated boreholes), packaging problems and poor storage processes.

It was found out during interactions with these nursing mothers that many of them do not boil the weaning food after the initial preparation with hot water. Thus, this poor heating treatment encourages the survival of the pathogen that would have been hitherto destroyed if the prepared foods were heated for few minutes before consumption. Table 1 also shows that highest bacterial loads were from food samples collected from uneducated mothers $\left(5.3 \times 10^{5}\right.$ and $4.8 \times 10^{5} \mathrm{cfu} \mathrm{mL}^{-1}$, respectively) for dawa and pap. This underscores the effects of ignorance on basic hygienic practices associated with food production and consumption. Furthermore, prolonged storage of the prepared foods in flasks and feeding bottles at ambient temperature and not in refrigerators encourage multiplication of the pathogens in the food.

From Table 1, dry industrially prepared weaning foods-custard, Golden Morn and Quaker oats had lower bacterial counts $\left(3.61 \times 10^{5}, 2.24 \times 10^{5}\right.$ and $2.13 \times 10^{5} \mathrm{cfu} \mathrm{mL}^{-1}$, respectively) than traditionally prepared weaning foods (dawa and pap) possibly due to quality control measures employed by the manufacturers. However, preparation and handling must have introduced contaminants into the otherwise sterile food materials. It's interesting to note that Golden Morn and Quaker oats weaning foods samples were not found with the uneducated mothers an indication of the effects of low socio-economic status of these mothers on the affordability of these better quality weaning food types.

The bacterial counts were also highest $\left(4.7 \times 10^{5} \mathrm{cfu} \mathrm{mL}^{-1}\right.$ from dawa) among food samples collected from the uneducated nursing mothers compared with the lowest count of $1.8 \times 10^{5} \mathrm{cfu} \mathrm{mL} \mathrm{m}^{-1}$ from the educated mothers. Results from Table 3 shows that the highest mean coliform count value of $2.63 \times 10^{5} \mathrm{cfu} \mathrm{mL}^{-1}$ is from uneducated mothers with pap having the highest individual value of $3.00 \times 10^{5}$ while the least mean coliform count value of $1.76 \times 10^{5} \mathrm{cfu} \mathrm{mL}^{-1}$ is from educated mothers with Golden Morn having individual value of $1.40 \times 10^{5} \mathrm{cfu} \mathrm{mL}^{-1}$. These trends are reflections of the need for formal education to the mothers, especially on food hygiene as well as the need for improvement in the hygienic conditions that prevail during the production and preparation of our traditional weaning foods-dawa and pap.

It was also found that the use of faecally contaminated water by many of the nursing mothers must have contributed a lot towards the contamination of the weaning foods fed to the infants as no pipe borne water was available in the area during this research work.

\section{CONCLUSION}

Results from the research work indicated contamination of all the weaning food types analyzed with such contamination arising from post fermentation processing such as unhygienic handling, use of contaminated water, poor heat treatment and prolong storage before consumption. Infants especially those aged between 2-8 months of age are very prone to a lot of infections due to their undeveloped immune system.

\section{RECOMMENDATIONS}

It is therefore very important that nursing mothers, house maids and every other person involved in handling infants foods either in production, preparation on consumption of weaning foods should be well informed about the hygienic conditions required hitherto to reduce or possibly eliminate infantile diarrhoea and morbidity. Mothers must ensure that they heat the prepared weaning food (boiling over water bath) to destroy pathogens in the food. In places where refrigeration is not possible, mothers and house maids should ensure that prepared weaning food is consumed immediately to prevent contamination and multiplication of pathogens upon prolonged storage. It is strongly recommended that treated pipe borne water should be made freely available to the indigenes of this community.

\section{REFERENCES}

Ashaye, O.A., S.B. Fasoyiro and R.O. Kehinde, 2000. Effects of processing on the chemical and sensory quality of ogi fortified with fat cowpea flour. Moor J. Agric. Res., 1: 115-223. 
Bekebian, D.A. 1989. Protein supplements in weaning food digest. Niger. Assoc. Food Sci. Technol. Stand., 1: $19-22$.

Bryan, F., 1988. Hazard analysis of food prepared by migrants living in a new settlements at the outskirts of lima, Peru. J. Food Prot., 51: 314-328.

Chessbrough, M., 2000. District Laboratory Practice in Tropical Countries. 2nd Edn., Cambridge University Press, UK., ISBN-0-521-66546-9, pp: 178-187.

Ifediora, A.C., C.K. Nkere and C.U. Iroegbu, 2006. Weaning food preparations consumed in umuahia, Nigeria: Evaluation of the bacteriological quality. J. Food Technol., 4: 101-105.
Leroy, F., J. Verluyten and L. De Vuyst., 2006. Functional meat starter cultures for improved sausage fermentation. Int. J. Food Microbiol., 106: 270-285.

Obi, C.L., P.B. Obong, A.S. Igumbor and R. Nengobela, 2005. Bacterial contamination of Vhuswa: A local weaning food and stored drinking water in impoverished households in Venda region of South Africa. J. Health, Population Nutr., 23: $150-155$.

Ogbulie, J.N., J.C. Uwaezuike and S.I. Ogiehor, 1998. Introductory Microbiology Practical. 1st Edn., Springfield Publishers, London, pp: 162. 